\title{
Familial Hypercholesterolemia: The Most Frequent Cholesterol Metabolism Disorder Caused Disease
}

\author{
Asier Benito-Vicente ${ }^{D}$, Kepa B. Uribe, Shifa Jebari, Unai Galicia-Garcia, Helena Ostolaza \\ and Cesar Martin *
}

Departamento de Bioquímica, Instituto Biofisika (UPV/EHU, CSIC), Universidad del País Vasco, Apdo.644, 48080 Bilbao, Spain; asierbenitovicente@gmail.com (A.B.-V.); kepa1985@gmail.com (K.B.U.);

shifajebari@gmail.com (S.J.); u.galiciag@gmail.com (U.G.-G.); elenaamaya.ostolaza@ehu.eus (H.O.)

* Correspondence: cesar.martin@ehu.eus; Tel.: +34-946-01-8053

Received: 29 September 2018; Accepted: 29 October 2018; Published: 1 November 2018

\begin{abstract}
Cholesterol is an essential component of cell barrier formation and signaling transduction involved in many essential physiologic processes. For this reason, cholesterol metabolism must be tightly controlled. Cell cholesterol is mainly acquired from two sources: Dietary cholesterol, which is absorbed in the intestine and, intracellularly synthesized cholesterol that is mainly synthesized in the liver. Once acquired, both are delivered to peripheral tissues in a lipoprotein dependent mechanism. Malfunctioning of cholesterol metabolism is caused by multiple hereditary diseases, including Familial Hypercholesterolemia, Sitosterolemia Type C and Niemann-Pick Type C1. Of these, familial hypercholesterolemia (FH) is a common inherited autosomal co-dominant disorder characterized by high plasma cholesterol levels. Its frequency is estimated to be 1:200 and, if untreated, increases the risk of premature cardiovascular disease. This review aims to summarize the current knowledge on cholesterol metabolism and the relation of $\mathrm{FH}$ to cholesterol homeostasis with special focus on the genetics, diagnosis and treatment.
\end{abstract}

Keywords: cholesterol; metabolism; familial hypercholesterolemia

\section{Cholesterol}

Cholesterol was first isolated from gallstones in 1789 during the French Revolution, and since then has been extensively studied. Nowadays, much information about its structure, function and implication in disease development is available [1].

Cholesterol is an essential component of cell barrier formation and cell signaling transduction [2,3] that regulates membrane fluidity and interacts with other lipids and proteins [4]. In addition, cholesterol affects the biophysical properties of the membrane by increasing lipid lateral order and membrane packaging and decreasing membrane fluidity and consequently membrane permeability [5]. Cholesterol can also regulate the function of many proteins, directly by interacting with them [4] or indirectly by its effects on membrane fluidity. Among cholesterol interacting proteins are proteins accepting cholesterol as a substrate (Acyl-CoA acyl-transferase (ACAT)) [6], proteins that need cholesterol-rich environments to effectively interact with the membrane (cholesterol-dependent cytolysins) [7], proteins with sterol binding domains (cleavage-activating protein (SCAP)) or hydroxymethylglutaryl-CoA reductase (HMG-CoA reductase) [8,9], proteins with cholesterol recognition amino acids consensus' (CRAC) domain and many others [10].

Cholesterol is also the precursor of many steroid molecules as bile salts, steroid hormones and vitamins. Bile salts are synthesized in the liver and are used as highly effective detergents that allow lipid solubilization [11,12]. In the case of hormones, cholesterol is the precursor of five major classes of steroid hormones: Progestagens, glucocorticoids, mineralocorticoids, androgens and estrogens [12]. 
Vitamin D is also a cholesterol derived molecule with a remarkable importance in calcium and phosphorus metabolism [13].

The complex functions mediated by cholesterol together with its role as precursor and its participation in metabolism pathways require a coordinated input and output regulation to achieve cholesterol homeostasis. This is of significant importance in order to avoid detrimental over-accumulation and abnormal deposition of cholesterol within the body that prevent diseases caused by a failure in cholesterol metabolism.

\section{Cholesterol Metabolism}

\subsection{Cholesterol Synthesis}

Cell cholesterol is mainly acquired from two sources: Dietary cholesterol [14] or intracellular synthesized cholesterol [15]. Almost all tissues have the ability to de novo synthesize cholesterol; however, the liver produces the majority of total body cholesterol [16,17]. De novo synthesis is a tightly regulated process where several proteins have an important role depending on the specific requirements. Hence, when intracellular cholesterol levels exceed physiologic need, sterol regulatory element-binding proteins (SREBPs) in the endoplasmic reticulum (ER) are inhibited. SREBPs are dedicated sterol sensors in the cell [18] and their activation promotes HMG-CoA reductase transcription (the limiting enzyme of the cholesterol synthesis) and concomitantly activates mevalonate (MVA) pathway to increase intracellular cholesterol synthesis. Cholesterol is synthesized in the ER in a 19 step process, then is secreted to the cytoplasm [19] where becomes available and can be distributed or stored as cholesterol esters (CEs) in lipid droplets after its esterification by ACAT [6].

\subsection{Cholesterol Absorption}

Dietary cholesterol absorption is the second source of cholesterol in the body after de novo synthetized cholesterol [20]. Cholesterol, free fatty acids (FFA) and triglycerides are the main lipids coming from the diet and are absorbed in the intestine [21]. Cholesterol absorption by the enterocytes is not an efficient process and for a correct uptake, cholesterol needs to be emulsified by bile acids. Bile acid emulsification generates cholesterol-bile acid micelles that can be delivered to the intestine. There, intestinal lipases hydrolyze cholesterol esters to free cholesterol that is taken up by the enterocytes through Niemann-Pick C1-like 1 (NPC1L1) protein [22]. NPC1L1 has a cholesterol-binding site in its $\mathrm{N}$-terminal domain exposed to the extracellular space and a C-terminal domain bound to the membrane. Free cholesterol interaction with NPC1L1 N-terminal domain, promotes a rearrangement in the intracellular domain of the protein that releases the YVNXXF-containing region from the membrane to the cytosol. Once in the cytosol, Numb, a clathrin adaptor protein, binds and promotes the internalization of the cholesterol-NPC1L1-Numb complex by clathrin coated pits (Figure 1A,B) [22,23]. 


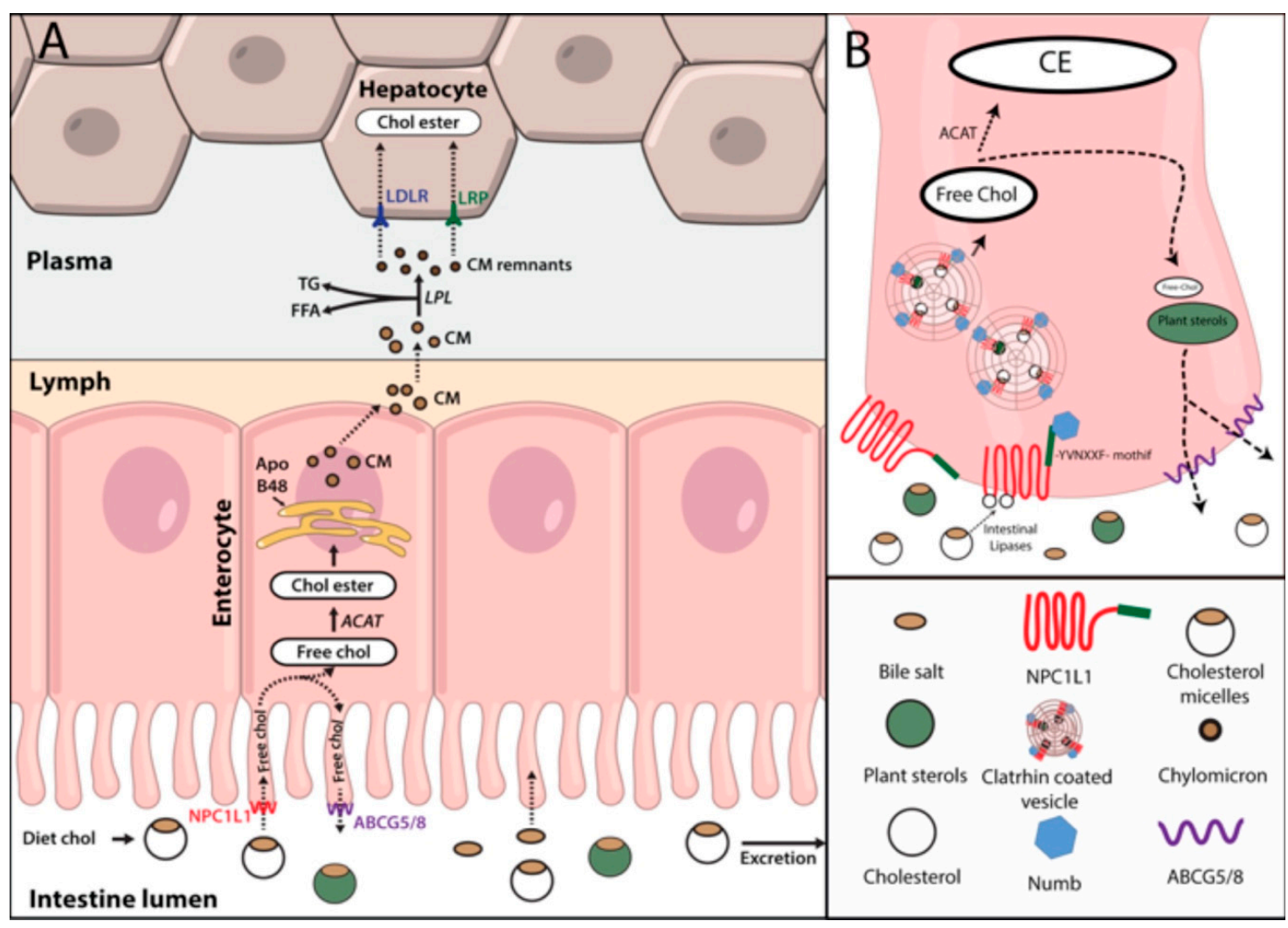

Figure 1. Dietary cholesterol absorption. (A) Diet cholesterol forms micelles in complex with bile acids and travel across the intestinal lumen where it is hydrolyzed and taken up by Niemann-Pick C1-like 1 in the enterocyte membrane. Internalized cholesterol can either be transported back to the intestinal lumen through ABCG5/8 along with plant sterols or esterified by Acyl-CoA acyl-transferase. Esterified cholesterol within other lipids is incorporated into chylomicrons and secreted to the lymph. Once in the lymph they are drained to the plasma where by lipoprotein lipases activity lose their triglycerides and become in chylomicron remnants that are finally taken up by the liver by low density lipoprotein receptor or LDLR related proteins. (B) Free cholesterol binds NPC1L1 and promotes its conformational change. This conformational change allows the binding of Numb adapter protein to YVNXXF motif and promotes its internalization in clathrin coated pits. Abbreviations: NPC1L1: Niemann-Pick C1-like 1; ACAT: Acyl-CoA acyl-transferase; Chol ester: Esterified cholesterol; CM: Chylomicrons; LPL: lipoprotein lipases; TG: Triglycerides; FFA: Free fatty acids; LDLR: low density lipoprotein receptor; LRPs: LDLR related proteins.

Once internalized, free cholesterol is delivered to ER where it is either transported back to the intestinal lumen via sterolins (ABCG5/8) or is re-esterified by ACAT. Re-esterified cholesterol can be stored in lipid droplets or directly be packaged together with triglycerides in apolipoprotein B48 (ApoB48) containing lipoproteins (chylomicrons) [24]. Contrary to ACAT, ABCG5/8 have high affinity for plant sterols. Along with ACAT, ABCG5/8 are responsible for the reduced absorption of the plant derived sterols. Indeed, mutations in $A B C G 5 / 8$ genes lead to an accumulation of plant sterols in the body, mainly sitosterol, causing a disease condition called sitosterolemia [25].

Chylomicrons are lipoproteins exclusively generated in the intestine during fasting; these particles contain ApoB48, a truncated form of ApoB100 that is produced by an alternative mRNA editing that determines the metabolic role of the chylomicron [26]. In the lipoprotein assembly process is essential the activity of the microsomal triglyceride transfer protein (MTP) [21]. Chylomicrons also contain a large variety of apolipoproteins, such as ApoA-I, ApoA-II, ApoA-IV, ApoA-V, ApoC-I, ApoC-II, ApoC-III or Apo-E, that are incorporated during chylomicron biogenesis or acquired from other circulating lipoproteins [27]. Newly synthesized chylomicrons are secreted into the lymph and 
transported through the lymphatic system [28] to the thoracic duct where the chylomicron rich lymph is drained into the bloodstream at the left subclavian vein [29]. Then, blood circulating chylomicrons interact with lipoprotein lipases (LPL) of peripheral tissues, primarily adipose and muscle tissue, where LPL is highly expressed [30]. ApoC-II of chylomicrons activates LPL leading to the hydrolysis of triglycerides [31,32]. The released FFAs are actively taken up by adipocytes and muscle cells through fatty acid transporters and CD36. Hydrolysis of FFAs from chylomicrons results in smaller particles enriched in cholesterol esters that transfer ApoA and ApoC to other lipoproteins (basically high density lipoproteins (HDL)) and acquire ApoE [33]. Finally, chylomicron remnants are cleared from the plasma by the liver, due to interaction of ApoE with low density lipoprotein receptor (LDLR) and other LDLR related proteins (LRPs) (Figure 2) [34].

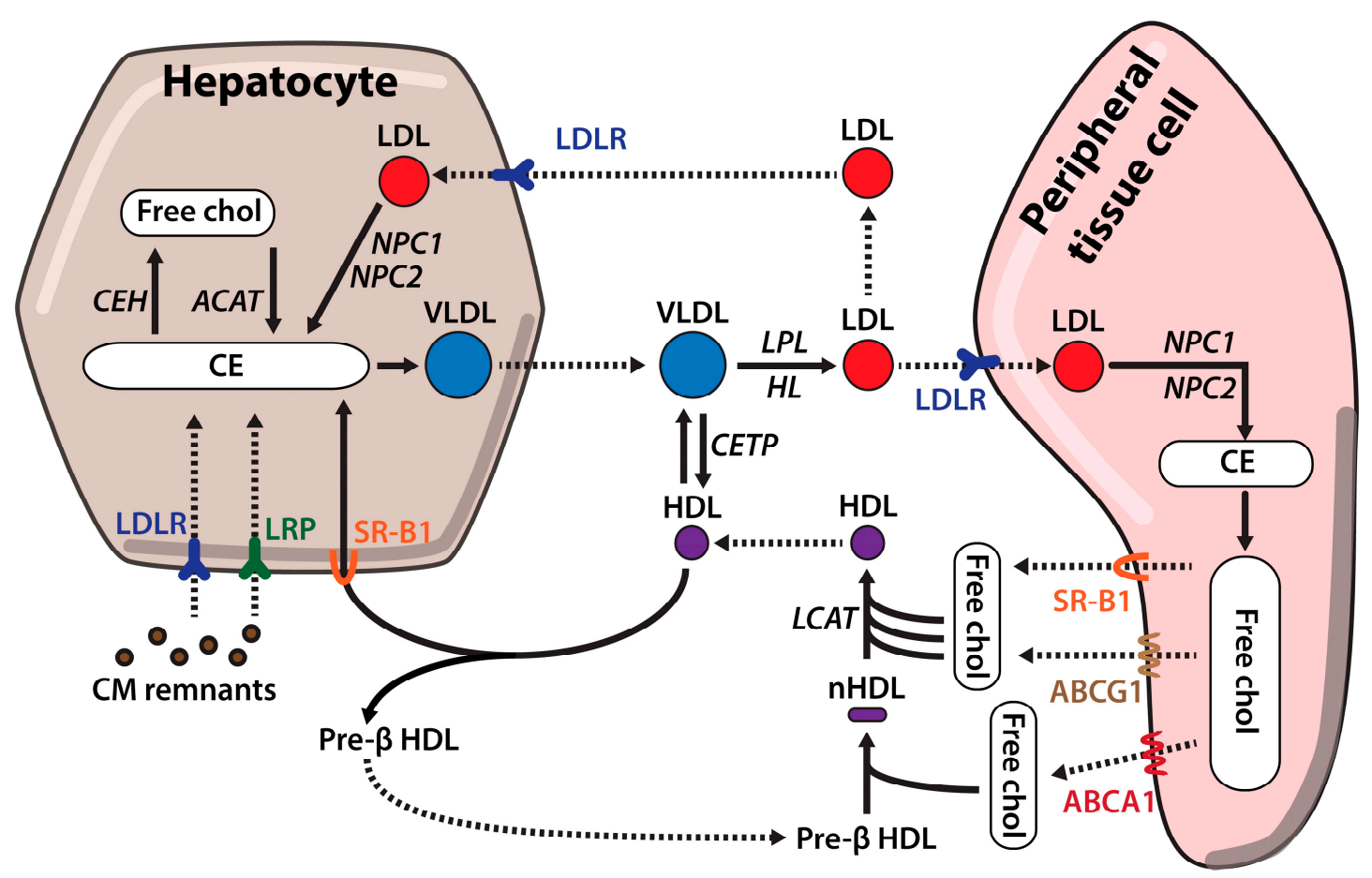

Figure 2. Cholesterol metabolism. Cholesterol is secreted from the liver to peripheral tissues in triglyceride rich lipoproteins, very low density lipoproteins. Once in the bloodstream, VLDL are transformed into cholesterol rich LDL particles by interaction with different proteins as LPL or exchange of lipids and apolipoproteins with high density lipoproteins LDL particles are taken up by peripheral tissue cells through LDLR. Excess cholesterol from peripheral tissues is packaged in HDL lipoproteins for it clearance. First, free cholesterol is transferred to lipid poor pre- $\beta$ HDL through ABCA1. Second, this first cholesterol loading changes HDL conformation and allow its interaction with ATP-binding cassette subfamily G member 1 and SR-B1 transporters that along with Lecithin-cholesterol acyltransferase produce mature HDL particles that are transported back to the liver for their clearance. Abbreviations: NPC1: Niemann-Pick C1; NPC2: Niemann-Pick C2; ACAT: Acyl-CoA acyl-transferase; CM: Chylomicrons; LPL: lipoprotein lipases; TG: Triglycerides; LDLR: low density lipoprotein receptor; LRPs: LDLR related proteins; VLDL: very low density lipoproteins; HDL: high density lipoproteins; ABCG1: ATP-binding cassette subfamily G member 1; LCAT: Lecithin-cholesterol acyltransferase; HDL: High density lipoproteins.

\subsection{Hepatic Cholesterol Efflux}

The liver is the primary organ regulating cholesterol homeostasis and plays a key role in cholesterol synthesis [16], lipoprotein synthesis and secretion [35], lipoprotein clearance [36] and cholesterol excretion among other processes [37]. Cholesterol is secreted from the liver in triglyceride rich lipoproteins known as very low density lipoproteins (VLDL). Regulation of VLDL synthesis and 
secretion is extremely well coordinated as they are critical for cholesterol distribution. VLDL synthesis is a two-step process that starts with the translocation of nascent apoB100 across the ER membrane of the hepatocytes and becomes lipidated by MTP [38]. If ApoB100 is not well lipidated, due to low triglyceride concentration or a failure in the process, the apolipoprotein is directed for degradation [39]. In a second step, partially lipidated VLDL particles are transported to the Golgi in vesicles containing coat protein complex II (COPII) [40]. Once in the Golgi they acquire apoA1 and apoE apolipoproteins and get further lapidated [41]. Finally, mature VLDL particles are secreted into the bloodstream and transport lipids to peripheral tissues [42].

High level secretion of VLDL by the liver can eventually be translated into high low density lipoprotein (LDL) levels in plasma and an enhanced cardiovascular risk [43]. On the other hand, an impaired VLDL secretion leads to lipid accumulation in the liver, which can be the starting step of fatty liver disease, therefore both processes need to be well coordinated and regulated [43,44].

\subsection{Cholesterol Influx}

Apart from de novo synthesized cholesterol, cells obtain cholesterol from the uptake of plasma lipoproteins through LDL receptor (LDLR) pathway [4]. In plasma, triglycerides from VLDL are removed by the action of LPLs and produce VLDL remnants also known as intermediate density lipoproteins (IDL). Additional IDLs processing by hepatic lipases (HL) together with exchange of lipids and apolipoproteins with HDL leads to low density lipoproteins (LDL) formation. LDLs are mainly composed by cholesterol esters and apoB-100 and they are the main cholesterol carriers of the body. They deliver cholesterol from liver to peripheral tissues where they bind LDLR and are endocytosed in clathrin coated pits [45]. Once LDL binds LDLR, LDL receptor adaptor protein 1 (LDLRAP1) recognizes the NPXY motif in the cytoplasmic tail of the LDLR and allows clustering of LDLR into clathrin-coated pits [46]. LDLR-LDL complex is delivered to endocytic compartment where, due to $\mathrm{pH}$ acidification, LDLR dissociates from LDL and is recycled back to the membrane due to $\mathrm{pH}$ dependent conformational change (Figure 3A). Dissociation of LDL from LDLR in the endosome is a key process that enables receptor recycling while LDL-cholesterol is hydrolyzed in the lysosome, because lysosomal lipase action to release free cholesterol [47-49]. Finally, free cholesterol is transferred from lysosomes to the ER by the action of Niemann-Pick type C1/C2 (NPC1/NPC2) proteins [50]. 

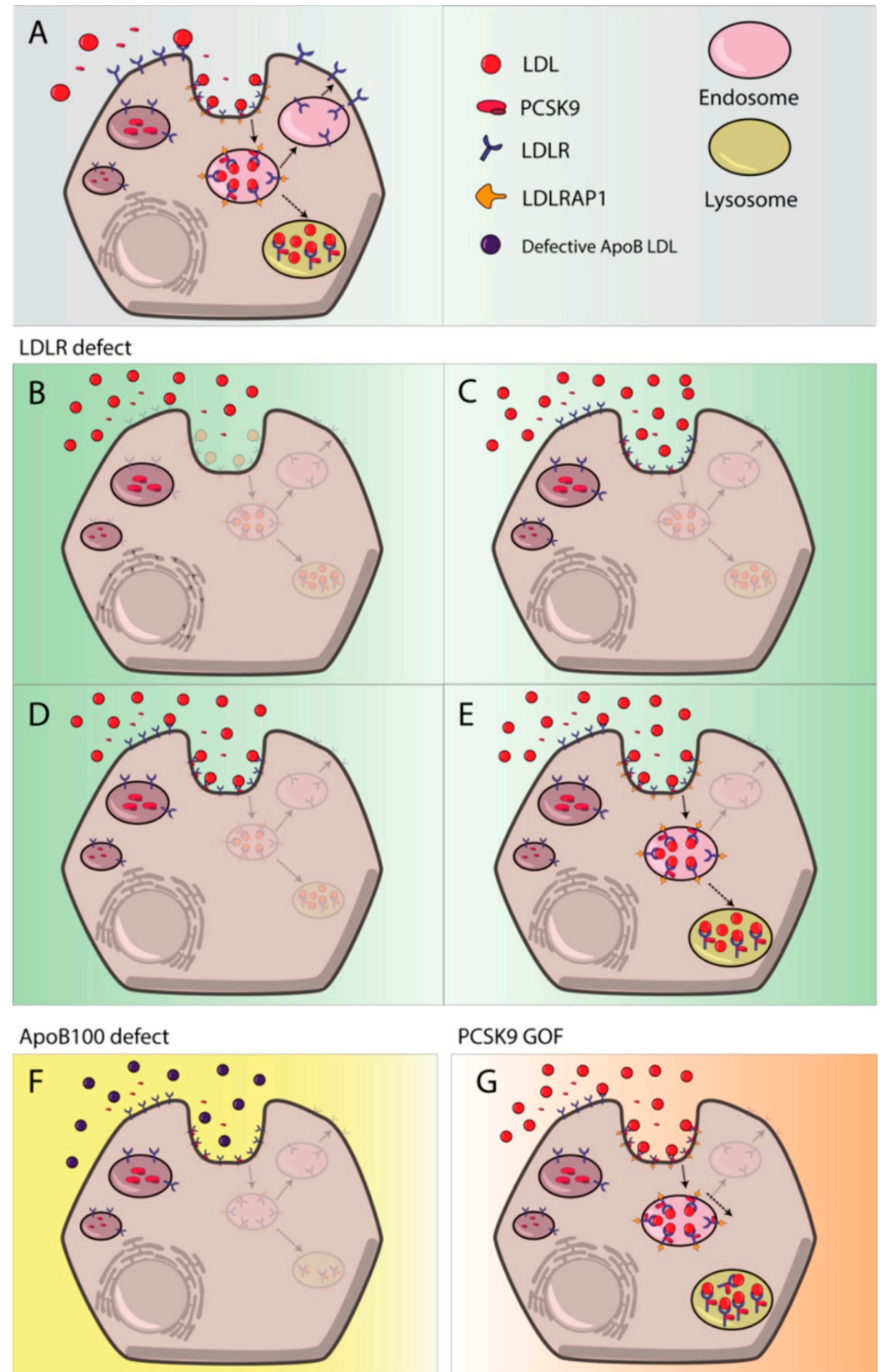

Figure 3. Most frequent LDL catabolism defects. (A) LDL uptake process by LDLR; (B) class 2 LDLR mutants, LDLR retention in the endoplasmic reticulum; (C) Class 3 mutants, no LDL-LDLR binding; (D) class 4 mutants, impaired LDL-LDLR complex internalization; (E) class 5 mutants, recycling defect;

(F) defective ApoB-100 derived impaired LDL-LDLR binding; (G) PCSK9 gain of function mutant.

\section{Cholesterol Influx Regulation}

LDLR mediated cholesterol internalization is a tightly regulated process with several checkpoints both at the transcriptional and post-transcriptional level [18,51,52]. On one hand SREBP-2, an inactive sterol regulatory element located in the ER, is activated at high intracellular cholesterol levels and translocates into the nucleus thus promoting $L D L R$ transcription $[18,53]$. On the other hand, proprotein convertase subtilisin/kexin 9 (PCSK9) [54] and IDOL, an inducible degrader of the LDLR, regulate LDLR at the membrane level by impairing the recycling of LDLR and promoting its degradation [55].

PCSK9 is the ninth member of the protein convertase family that is synthesized as a proprotein and requires an autocatalytic cleavage to become mature [56]. The result of the cleave is a N-terminal prodomain that remains bound to the catalytic domain and inhibits convertase function [57]. 
Mature PCSK9 is secreted to the extracellular medium where it binds epidermal growth factor A (EGF-A) domain of the LDLR and the complex is internalized by clathrin-mediated endocytosis. Upon endosome acidification, affinity of PCSK9 to LDLR increases thus impairing the required conformational change of LDLR for recycling. The non-dissociated PCSK9-LDLR complex is then delivered to the lysosome [58,59].

IDOL, like PCSK9, regulates LDLR pathway post-transcriptionally. IDOL is an E3 ubiquitin ligase that mediates ubiquitination and degradation of LDLR [60]. IDOL expression is induced by oxysterols, generated due to high intracellular cholesterol concentration; activated cholesterol sensing nuclear receptors (LXRs) enhances IDOL expression along with genes involved in reverse cholesterol transport (RCT) [61]. The up-regulation of IDOL promotes ubiquitination of the cytoplasmic tail of the LDLR and its subsequent degradation $[51,60]$.

Additionally, epigenetics and post-translational modifications of LDLR are important for LDLR mediated lipoprotein uptake [62-64]. For instance, microRNAs (miRNAs) have an active role in modulating efficiently LDLR expression. miRNAs are small single stranded non-coding RNAs with the ability to inhibit mRNA translation. They are synthesized as 70-100 nucleotide pri-miRNA, which are sequentially modified by Drosha and Dicer endonucleases to produce mature miRNAs [65]. The mature miRNAs are about $20 \mathrm{nt}$ long molecules that are incorporated into RNA-induced silencing complex (RISC) to target mRNAs for their translational repression [66]. Many studies have shown that miRNAs are important regulators of the LDLR dependent LDL uptake. Indeed, miR-27b [67], miR-27a [68], miR-148a [69] and miR-128-1 [64] among other miRNAs are able to directly bind the $3^{\prime} \mathrm{UTR}$ of the LDLR mRNA and selectively degrade it.

\subsection{Reverse Cholesterol Transport (RCT)}

RCT is a tightly controlled mechanism by which the body is able to excrete the excess of cholesterol from peripheral tissues through the liver to the feces [70]. In this process, ApoA- 1 containing HDL are the mayor cholesterol acceptor from extra-hepatic tissues and the main responsible for cholesterol excess clearance [71].

RCT begins by interaction of ApoA-1 lipid free particles (pre- $\beta$ HDL) with the ATP-binding cassette transporter A1 (ABCA1) in the plasma membrane that promotes free-cholesterol efflux from the endocytic compartment [71]. Lipidation of pre- $\beta$ HDL induces conformational changes within the lipoprotein that adopts a discoid shape thus becoming a nascent-HDL. Free cholesterol is then esterified by Lecithin-cholesterol acyltransferase (LCAT) generating spherical mature HDL with a CE core [72]. In addition to ABCA1, the mature HDL can interact with other cholesterol transporters as ATP-binding cassette subfamily G member 1 (ABCG1) or Scavenger receptor class B type 1 (SR-B1) enhancing free-cholesterol efflux from peripheral tissues and increasing HDL particles size [36,72,73]. Passive cholesterol transport from cell membranes to nascent HDL also contributes to cholesterol loading of the lipoprotein [74]. Once HDL are fully lipidated, they are transported to the liver where CEs are selectively removed by SR-B1 for their excretion into bile (Figure 2) [36].

Interactions between different lipoproteins are also common during RCT. Mature HDL exchange both, proteins and lipids with other lipoproteins in plasma. CEs are transferred from the core of the mature HDL to VLDL by the action of cholesterol ester transfer protein (CETP) and receives triglycerides in exchange [75]. As a consequence, VLDL remnants are generated and converted to LDL that can either be removed by LDLR in extra-hepatic tissues or by the liver for excretion into bile [76].

\subsection{Bile Acid Excretion}

Cholesterol excretion into bile is the last step in cholesterol elimination [76]. Bile acids are key modulators of cholesterol homeostasis and the main component of the bile. As mentioned before, they are essential for diet cholesterol emulsification and absorption and they also participate in the excretion of cholesterol leftovers from the liver [77]. Bile acids are primarily synthesized from cholesterol in the liver through a complex pathway strongly regulated by a feedback mechanism [78]. 
Once synthesized, they are pumped out by ABCB11 (also known as bile salt export pump (BSEP)) and promote secretion of phospholipids and cholesterol to the canalicular plasma, leading to micelle formation [37]. Cholesterol transport to the bile is mainly enhanced by ABCG5/8 heterodimer $[79,80]$ and requires phospholipids because they are a critical component for micelle formation. Indeed, defective phospholipid transport by ABCB4 (historically named multi-drug resistance P-glycoprotein 2(MDR2)) almost completely eliminates cholesterol secretion [81]. Finally the micelles are stored within the gallbladder and released into the intestinal lumen after food ingestion-produced stimuli [82].

In summary, cholesterol metabolism is a complex mechanism with many factors involved that requires a high level of coordination. Cholesterol absorption in the enterocytes, lipoprotein transport, cholesterol uptake in peripheral tissues and cholesterol excretion in the liver are tightly controlled processes that allow a correct balance of cholesterol in the organism. Hence, deregulation of these processes or mutation affecting proteins involved in these pathways can be disease causing. Mutations that alter LDL metabolism are the most frequent defects leading to a cholesterol metabolism derived disease denominated familial hypercholesterolemia.

\section{Familial Hypercholesterolemia}

Familial hypercholesterolemia (FH) is a common inherited autosomal co-dominant disorder primarily characterized by high plasma levels of low-density lipoprotein cholesterol (LDL-C), due to its reduced catabolism [14]. If untreated, exposure to high LDL-C levels during lifetime increases atherosclerotic plaque development and premature cardiovascular disease risk [83].

$\mathrm{FH}$ prevalence in its heterozygous form $(\mathrm{HeFH})$ has traditionally been considered to be approximately 1:500. However, frequency can vary between 1:200 and 1:300 depending on which criteria are used to define FH (mutation only, LDL-C threshold only, clinical score or a combination of factors) and the studied populations [84]. Regarding the homozygous form of the disease (HoFH), the prevalence has traditionally been estimated in 1:1,000,000, but recent studies have revealed a prevalence upwards to 1 in 300,000 [84].

\subsection{Genetics of FH}

Cholesterol metabolism and its distribution is a complex system in which many proteins and pathways are involved. LDL catabolism is one of the key points in this process and any defect in its function by any of the proteins taking part on it can generate $\mathrm{FH}$. The major determinants in that system are LDLR, accounting for $80-85 \%$ of FH cases, apoB100, causing $5-10 \%$ of the cases, PCSK9 $2 \%$ of the cases and LDL receptor adaptor protein 1 (LDLRAP1) accounting for less than $1 \%$ of the cases [85]. Mutations in APOE [86], signal transducing adaptor family member 1 (STAP1) [87], lysosomal acid lipase (LIPA) [47], ABCG5 or ABCG8 [88] genes can also generate a FH like phenotype, but its frequency is very low in all of the cases.

\subsection{1. $L D L R$}

LDLR with more than 3000 variants already reported (Clin Var database [89]) is one of the key genes responsible of FH development [49]. LDLR removes LDL from plasma circulation (Figure 3A) and malfunctioning of LDLR is commonly associated with high levels of circulating LDL-C. Many different $L D L R$ variants have been described as pathogenic, including large-scale DNA copy number variation $(\mathrm{CNV})$, insertion and deletions, nonsense and missense mutations and splicing mutations $[85,90,91]$. CNV, nonsense and splicing mutations are commonly associated with higher LDL-C levels [49,92-94] than missense mutations. LDLR mutations can affect at different steps of the LDL uptake system and thus can be classified depending on their phenotypic behavior as: Class 1 mutants are characterized by a null protein synthesis; class 2 mutants are partially or completely retained in the endoplasmic reticulum (Figure 3B); class 3 mutants have a binding defect and are not able to properly interact with apoB apolipoprotein (Figure 3C); class 4 mutants have an impaired 
endocytosis (Figure 3D) and finally class 5 mutants affect the recycle mechanism and LDLR cannot be recycle back to the membrane (Figure $3 \mathrm{E}$ ).

\subsection{2. $A P O B$}

Mutations in $A P O B$ are a second cause of $\mathrm{FH}$ with a phenotype known as familial defective APOB [85]. Mutations in $A P O B$ gene were first detected in the highly conserved receptor binding-site (exons 26 and 29) [95] leading to deficient binding to LDLR. Recently some studies have also described new variants out from the consensus binding site of the $A P O B$ [96], these variants have been functionally characterized and classified as pathogenic indicating that LDLR-LDL binding could be more dynamic than expected [48]. $A P O B$ pathogenic variants are associated with lower LDL-C levels than those observed with $L D L R$ pathogenic variants (Figure 3F).

\subsubsection{PCSK9}

PCSK9 variants started to be described in the early 2000s when PCSK9 locus was mapped [54]. These variants can either be loss of function (LOF) variants, generating less functional proteins or gain of function variants (GOF) producing more active proteins [97]. GOF variants are associated with increased LDL-C levels as they enhances degradation of LDLR extracellularly, due to increased affinity (Figure 3G) or intracellularly while it is been transported to the membrane [98]. Both mechanisms lead to a reduced expression of LDLR resulting in plasma LDL accumulation. To date, more than 30 GOF PCSK9 variants have been reported; most of them missense mutations located all around the 3 domains of PCSK9 [97]. Different mechanisms underlying the increased activity, including increased transcription, altered autocatalysis or enhanced binding ability for the receptor have been described [97]. LOF mutations are less common than GOF mutations and are associated with lower LDL-C levels and reduced cardiovascular disease [99].

\subsubsection{LDLRAP1}

LDLRAP1 mutations constitute the fourth most common protein defects among LDLR cycle proteins and cause autosomal recessive hypercholesterolaemia [100]. Pathogenic mutations in both alleles of the gene impair LDLR-LDL complex internalization. A dysfunctional LDLRAP1 does not allow proper clathrin coated endosome formation and inhibits LDL uptake thus increasing plasma LDL-C accumulation [101,102].

\subsection{Second Generation FH}

High cholesterol levels are frequently associated to genes or processes related with cholesterol trafficking, but sometimes they can be a consequence of other diseases or environmental factors. Mutations in ABCG5 or ABCG8 genes cause sitosterolemia, in which patients present increased LDL-C levels, some characteristic FH phenotype features and higher cardiovascular risk, alike FH [103,104]. The main cause of this manifestation is plant-sterol accumulation, therefore its treatment consist sterol absorption inhibitors administration instead of statin treatment [25]. Nephrotic syndrome (NS) is also associated with an increased cholesterol and triglyceride accumulation. Patients with acute NS have marked proteinuria that generates an increased synthesis of lipoproteins in the liver $[105,106]$. Liver failure [107], hypothyroidism [108] or cholestasis are other diseases associated with higher levels of plasma cholesterol and an increased risk of cardiovascular disease [109].

\subsection{FH Implication in Cardiovascular Disease}

FH is characterized by abnormally increased levels of LDL-C, which promotes early atherosclerosis development [84]. Atherosclerosis is the underlying cause of cardiovascular disease, increasing the risk of heart attack, stroke and peripheral vascular disease [110]. In FH patients, accumulated plasma LDL-C particles and VLDL remnants cross the endothelial lining of the arteries and get retained in the 
subendothelial compartment where they become oxidized [111]. This lipid accumulation is enhanced in places where the endoplasmic barrier and the junction between endothelial cells are weaker, mainly in arterial curves and branches where a disturbed blood flow causes higher stress [112]. Endothelial cells increase the secretion of different adhesion and chemoattractant molecules in response to oxidized particle stimuli thus generating monocyte recruitment and trans-endothelial cell migration [113]. Once in the subendothelial space, monocytes differentiate to proinflamatory macrophages and start to internalize modified lipoproteins through a non-regulated variety of scavenger receptors (SRs) [114]. The excess of cholesterol in macrophages induces foam cell formation and enhances their proinflamatory fate by promoting migration of vascular smooth muscle cells (VSMC) and proliferation of those macrophages already present in the intima. Finally, activated VSMC start the production of the fibrous cap, an extracellular matrix composed primarily of collagen, elastin and proteoglycans [115]. As atherosclerosis progresses, the necrotic core, covered by the fibrous cap, increases in size as a consequence of increased macrophage death and impaired efferocytosis (Figure 4). This process reduces the diameter of the arteries causing lumen occlusion; furthermore, at this stage, proinflamatory cells present in the plaque start to secrete matrix metalloproteinases (MMPs) that degrade the extracellular matrix of the fibrous cap. This process promotes plaque rupture ensuing formation of thrombi by platelet aggregation and ischemic event thus increasing the risk heart attack and peripheral vascular disease [116,117].

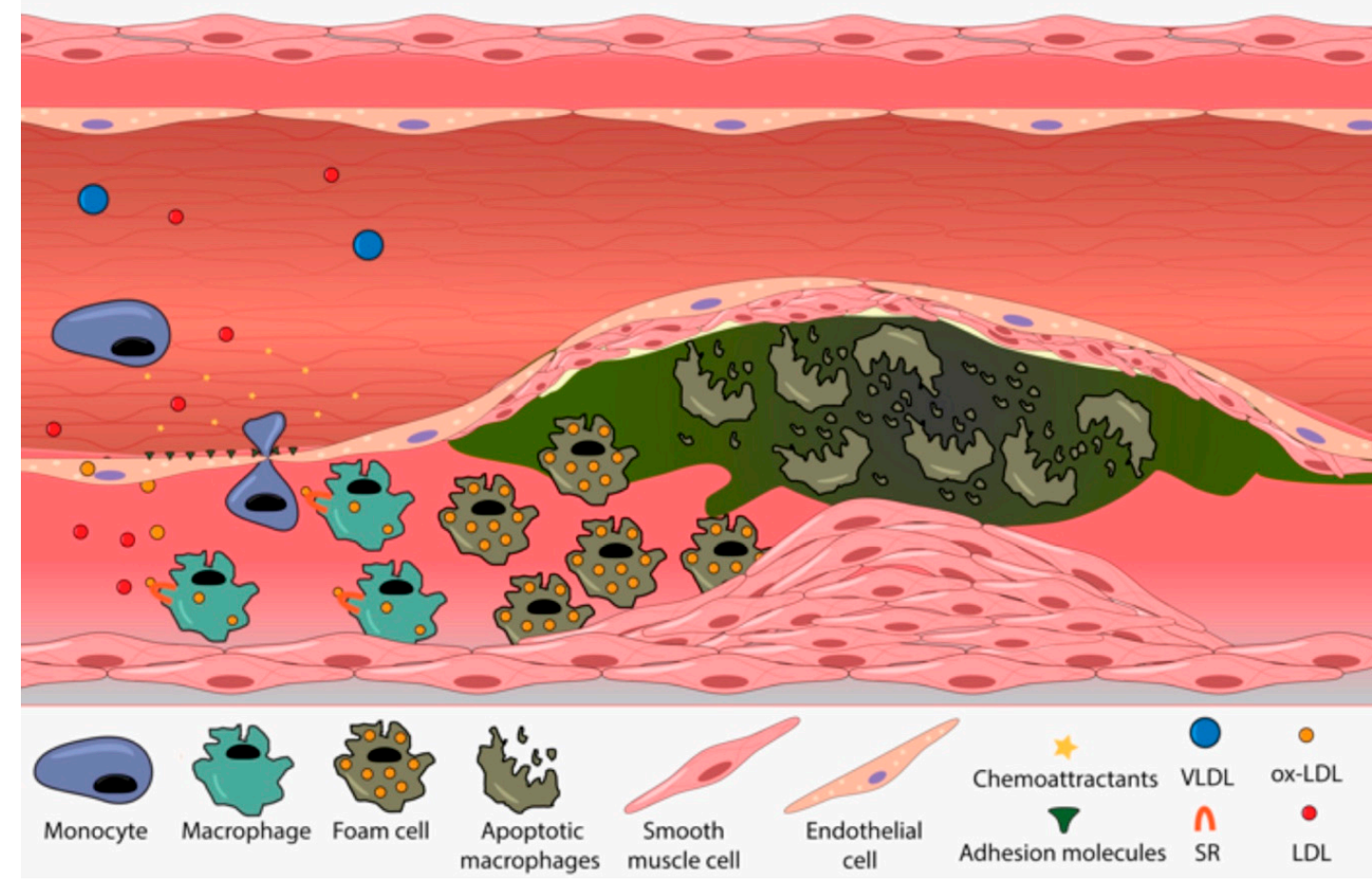

Figure 4. Atherome plaque development. Accumulated LDL particles cross endothelial barrier and get oxidized in subendothelial space. Lipoprotein oxidation activates endothelial cells that increase the synthesis and secretion of chemoattractants and adhesion molecules promoting monocyte recruitment and transedothelial migration. Once at sub-endothelial compartments they are differentiated into machrophages and start to internalize ox-LDL through a non regulated SR-B1 scavenger receptor. Cholesterol excess in macrophages induces foam cell formation and promotes SVMC migration and fibrous cap synthesis. Finally, due to increased macrophage death and impaired efferocytosis, the size of the plaque increases and the diameter of the artery is reduced. 


\subsection{FH Diagnosis}

Different guidelines are available for FH diagnosis. Among them, Simon Broome Register Group (SBRG) [118], Make Early Diagnosis to Prevent Early Death (MEDPED) [119] and Duch Lipid Clinic Network (DLCM) [85] are the most extended ones. All the guidelines share common criteria with small differences in the threshold and, combination of factors needed for a definitive FH diagnosis, including physical symptoms (tendinous xanthomata and arcus cornealis if under 45 years old), plasma cholesterol levels (if are over $330 \mathrm{mg} / \mathrm{dL}$ is a definite diagnose), familial history of $\mathrm{FH}$, clinical history of the patient and DNA analysis.

\subsection{Evolution of Lipid Lowering Therapies}

High cholesterol levels do not have any direct symptoms so many people usually ignore that they suffer FH. Typically, $200 \mathrm{mg} / \mathrm{dL}$ total cholesterol and $100 \mathrm{mg} / \mathrm{dL}$ LDL-C are considered threshold values over from which the risk of suffering CVD increases dramatically [120]. Therefore, prevention and treatment of FH is critical. Nowadays, statins constitute the gold standard treatment of $\mathrm{FH}$, but historically other drugs or drug-combination have been commonly used. Additionally, statin treatment in some cases of $\mathrm{HeFH}$ and in $\mathrm{HoFH}$ only show promising results if combined with other cholesterol lowering therapies [121,122].

\subsubsection{Statins}

Statins are the most frequently prescribed blood-lipid lowering drugs in the world. They inhibit HMG-CoA reductase and the downstream metabolite production of mevalonate pathway, which is a key step on the production of cholesterol in the liver [1-3]. As a consequence, intracellular cholesterol production highly decreases thereby inducing LDLR expression on the hepatocyte cell membrane leading to decreased circulating LDL-C concentrations. Indirectly, statins increase LDL and even VLDL clearance from the plasma, due to overexpression of LDLR in the liver and peripheral tissues [123]. In addition to this, statins also have beneficial effects on other lipid parameters, including increases in HDL levels and decreases in triglyceride concentration. Statins were discovered in the early 70s by Akira Endo, but not commercially available until 1986 when lovastatin was commercialized as the first HMG-CoA reductase inhibitor [123]. Currently, the most frequently used statins are lovastatin, fluvastatin, atorvastatin, sinvastatin and rosuvastatin. The most potent ones: Rosuvastatin, atorvastatin and sinvastatin can also reduce LDL levels in HoFH patients probably because of lower LDL-C production in the liver [124].

Statins can be grouped in two types. Type 1 statins, derived from natural sources or modifications of natural molecules (lovastatin, simvastatin, mevastatin and pravastatin); and, type 2 statins that are synthetic in which typically a fluorophenyl group substitutes the butyrl group present in type 1 statins (atorvastatin, fluvastatin, rosuvastatin, cerivastatin and pitavastatin). Statin hydrophilicity is determinant for their hepatoselectivity. Acording to it, they can be classified into two categories: Hydrophilic (rosuvastatin and pravastatin) and hydrophobic (atorvastatin, simvastatin, fluvastatin, lovastatin and cerivastatin) $[125,126]$. Both categories are selectively absorbed in hepatocytes however, they show differential absorption in peripheral tissues $[127,128]$. Hydrophobic statins tend to have higher exposure in non-hepatic tissues because they can passively diffuse through cell membranes whereas hydrophilic statins are more liver specific because they use active transporters to be taken up by hepatocytes. Differences in the differential metabolism of lipophilic and hydrophilic statins provide a mechanism underlying the adverse metabolic consequences. Lipophilic statins are metabolized via cytochrome P450 (CYP450 family of enzymes) to a water-soluble form for renal excretion. In contrast, the water-soluble statins depends less or not at all on the CYP450 system and are excreted largely unchanged being less subject to pharmacokinetic interactions.

Although high efficacy and safety of the statins has been demonstrated, long-term high-dose treatments studies have revealed some adverse effects in some individuals. The most common ones are 
the statin-associated muscle symptoms as muscle pain or weakness [129], therefore water soluble statins (pravastatin, rosuvastatin) are preferred. The influence of statins on the development of type II diabetes mellitus (DMII) is also under study. Indeed, high dose statin treatment has been implicated in the development of DMII [130]. Specifically, lipophilic statins may have adverse metabolic consequences that include impaired insulin secretion and promotion of insulin resistance, whereas water soluble statins are better tolerated. Several adverse effects on hepatic, renal or even cognitive function should not be discarded [131].

\subsubsection{Niacin}

Niacin, also called vitamin B3 or nicotinic acid, was the first lipid-modifying drug used for the treatment of FH. Niacin reduces FFA mobilization from adipose tissue by inhibiting its protein lipase system. Therefore, the reduced FFA availability in liver impairs synthesis of cholesterol and triglyceride containing particles. The common side effects of niacin are vasodilatation and elevation of hepatic enzymes [132].

\subsubsection{Bile Acid Sequestrants}

Bile acid sequestrants were introduced in the market in 1975 [133]. These molecules form insoluble complexes with bile acid-cholesterol micelles thus avoiding capture by enterocytes and consequently the micelles are excreted [134]. Because enterocyte-liver cholesterol transit is partially inhibited, liver cholesterol levels are reduced so LDL and VLDL secretion is reduced and consequently their bloodstream concentration [135]. They are proven to reduce both cardiovascular events and derived mortality however; they are usually not well tolerated. Indeed, they interfere with absorption of some fat-soluble vitamins and also with bile acids reabsorption that, in normal condition, are almost entirely reabsorbed. They are not useful in cases of HoFH with null receptor function [136].

\subsubsection{Ezetimibe}

Ezetimibe is a selective cholesterol absorption inhibitor that blocks the uptake of cholesterol. It inhibits NPC1L1 both at enterocyte lumen and hepatobiliary interface affecting cholesterol, but not trygliceride or fat-soluble vitamin absorption [137]. The inhibition of cholesterol absorption in the intestine results in a reduced chylomicron formation and secretion in addition to bile cholesterol reabsorption inhibition. The sum of these effects leads to a depletion of cholesterol stores in the hepatocytes. Reduced cholesterol content in the liver favors LDLR expression, as well as reduced VLDL generation resulting in lower LDL-C in plasma [138].

\subsubsection{Human Monoclonal Anti-PCSK9 Antibodies}

Human monoclonal anti-PCSK9 antibodies have been demonstrated to lower LDL-C levels efficiently and reduce CVD especially in high risk patients [139]. Their use is recommended when neither statins nor ezetimide is able to reduce cholesterol under recommended levels [140]. Currently, two different monoclonal antibodies are available, Alirocumab and Evolocumab. Both are Human IgG subtypes that bind circulating PCSK9 and inhibit their binding to LDLR leading to a PCSK9 deficiency-like condition [141]. The absence of functional PCSK9 enhances LDLR recycling and its availability in the membranes thus favoring LDL clearance from the plasma. While anti-PCSK9 antibodies have low side effects and high efficacy in comparison with other drugs, the high cost of the therapy remains a barrier for more widespread implementation of anti-PCSK9 treatments [141].

\subsubsection{Other Treatments}

Recently some drugs affecting lipoprotein synthesis have been introduced. Lomitapide is a MTP inhibitor, a protein responsible for the assembly of lipids onto the proteins both in hepatocytes and enterocytes. Mipomersen is an antisense oligonucleotide that binds apoB mRNA reducing VLDL and 
LDL generation in the liver. Both drugs have been associated with many side effects and their use is not recommended except in cases of HoFH or very high cardiovascular risk [142].

Lipoprotein apheresis (LA) is a therapeutic tool normally used in extremely high-risk patients where other therapies have not worked or appear to be not effective. HoFH is a clear example where LA is recommended $[143,144]$. Usually HoFH patients with no LDLR expression have residual response to statin treatment and monoclonal antibodies against PCSK9 are rarely effective. In those cases, with a really high risk of CVD and poor prognosis LA therapy should be started [143]. LA is only recommended when other lipid lowering drugs are ineffective, due to its high cost and time consuming. In fact, the accessibility to LA is reduced to a few countries [133].

To date, statins are the main used cholesterol-reducing drug, both due to their high efficacy and low cost [140]. They are recommended as first treatment option and only statin-intolerant patients and patients under statin treatment not achieving recommended LDL-C values, the use of other drugs should be suggested. In cases in which statins have low effect, they are usually combined with ezetamibe, PCSK9 inhibitors or both with promising results [140]. In HoFH with non LDLR function, MTP inhibitors or apoB inhibiting oligonucleotides are appropriate the choice to reduce LDLR levels assuming their low tolerability and high cost [141].

\subsection{Nutraceuticals in FH}

Nutraceuticals are natural lipid regulating products recommended in combination with the previously described therapies for different dyslipidemias management [145]. Nutraceuticals are able to affect at different steps of cholesterol metabolism and can improve the effects of the different cholesterol reducing therapies. Plant sterols and green tea are able to reduce dietary cholesterol absorption [146,147], berberine (extracted from a variety of plants) inhibits PCSK9 action [148,149] and monacolins, present in red yeast rice, share structural similarities with statins and inhibit intracellular cholesterol synthesis [150].

\subsection{Current FH Situation}

As mentioned before, untreated FH increases 13 fold the risk of CVD [151]. Sustained high plasma cholesterol levels induces lipoprotein oxidation and infiltration through endothelial barrier enhancing and accelerating progression of atherosclerotic plaque. Nowadays many high efficacy cholesterol reducing therapies are available and their efficacies have been probed [151]. However, the main issue in FH treatment is the underdiagnosis of this disease. In most countries, less than $1 \%$ of the population has been diagnosed and only in The Netherlands have diagnosed more than $50 \%$ of their population. In Spain for example, the diagnose condition is reduced to the $6 \%$ of the population $[85,152]$. Taking into account that the estimated prevalence of the disease is 1:200-1:300 and global numbers reveal less than $1 \%$ of diagnosed population, there are about 24 and 36 million of $\mathrm{FH}$ individuals with non definitive $\mathrm{FH}$ diagnose and high risk of premature CVD.

Historically, HeFH has been clinically diagnosed based on LDL-C levels, tendon xanthomas, or familial history of coronary artery disease. This kind of diagnosis was able to detect the most severe cases of $\mathrm{HeFH}$ and $\mathrm{HoFH}$, but many mild FH phenotypes were not identified. Through improvements in understanding of $\mathrm{FH}$ and the development of new generation sequencing techniques, $\mathrm{FH}$ mutations causing mild FH phenotypes are now more easily detected. Combinations of both genetic testing and clinical criteria have enabled detection of mild FH phenotype patients and identification of patients with clinical FH and without mutation in FH generating classical genes [152,153].

Differences in LDL-C levels between FH causing mutation carriers with non-carriers vary with age. At young ages, the differences in LDL-C levels are higher than in people over 55 years old, so differences in LDL-C accumulation are set up mainly in early stages of the disease underlying the importance of an early diagnosis and treatment of the FH [154]. Moreover, early treatment of the disease makes possible an efficient low dose statin treatment instead of high dose treatments required 
in cases where the FH is diagnosed later in life, thus side effects derived from aggressive statin use are avoided [131].

\subsection{Functional Studies as a Complement to Genetic Testing}

Genetic testing is proven to be the best mechanism for a correct early FH diagnosis. However, because the great majority of the variants are not functionally characterized, genetic testing must be complemented to provide an accurate and definitive diagnose [155]. Cosegregation studies, functional studies or a combination of both are good alternatives to complement genetic studies. Cosegregation studies unlike functional studies have the limitation of clinical data availability and alteration carrier number [156]. Functional studies instead can be performed in any research laboratory and not only give information about the pathogenicity, but also about the disease causing mechanism of the different mutations $[48,49,157,158]$.

Funding: This work was supported by ELKARTEK 2016 and the Basque Government (Grupos Consolidados IT849-13). A.B.-V. and S.J. were supported by a grant PIF (2014-2015) and (2018-2021), Gobierno Vasco respectively.

Acknowledgments: We sincerely thank Haziq Siddiqi (Harvard Medical School) for his critical reading and editing of this manuscript, and Jonan Nieto (Biofisika Institute (UPV/EHU, CSIC)) for his assistance in image editing.

Conflicts of Interest: The authors declare no conflict of interest.

\section{References}

1. Maxfield, F.R.; Tabas, I. Role of cholesterol and lipid organization in disease. Nature 2005, 438, 612-621. [CrossRef] [PubMed]

2. Cherezov, V.; Rosenbaum, D.M.; Hanson, M.A.; Rasmussen, S.G.F.; Thian, F.S.; Kobilka, T.S.; Choi, H.-J.; Kuhn, P.; Weis, W.I.; Kobilka, B.K.; et al. High-Resolution Crystal Structure of an Engineered Human 2-Adrenergic G Protein-Coupled Receptor. Science 2007, 318, 1258-1265. [CrossRef] [PubMed]

3. Ikonen, E. Cellular cholesterol trafficking and compartmentalization. Nat. Rev. Mol. Cell Biol. 2008, 9, 125-138. [CrossRef] [PubMed]

4. Grouleff, J.; Irudayam, S.J; Skeby, K.K.; Schiøtt, B. The influence of cholesterol on membrane protein structure, function, and dynamics studied by molecular dynamics simulations. BBA Biomembr. 2015, 1848, 1783-1795. [CrossRef] [PubMed]

5. Yang, S.-T.; Kreutzberger, A.J.B.; Lee, J.; Kiessling, V.; Tamm, L.K. The role of cholesterol in membrane fusion. Chem. Phys. Lipids 2016, 199, 136-143. [CrossRef] [PubMed]

6. Rogers, M.A.; Liu, J.; Song, B.-L.; Li, B.-L.; Chang, C.C.Y.; Chang, T.-Y. Acyl-CoA:cholesterol acyltransferases (ACATs/SOATs): Enzymes with multiple sterols as substrates and as activators. J. Steroid Biochem. Mol. Biol. 2015, 151, 102-107. [CrossRef] [PubMed]

7. Christie, M.P.; Johnstone, B.A.; Tweten, R.K.; Parker, M.W.; Morton, C.J. Cholesterol-dependent cytolysins: From water-soluble state to membrane pore. Biophys. Rev. 2018, 1-12. [CrossRef] [PubMed]

8. Gao, Y.; Zhou, Y.; Goldstein, J.L.; Brown, M.S.; Radhakrishnan, A. Cholesterol-induced conformational changes in the sterolsensing domain of the Scap protein suggest feedback mechanism to control cholesterol synthesis. J. Biol. Chem. 2017, 292, 8729-8737. [CrossRef] [PubMed]

9. Theesfeld, C.L.; Pourmand, D.; Davis, T.; Garza, R.M.; Hampton, R.Y. The sterol-sensing domain (SSD) directly mediates signal-regulated endoplasmic reticulum-associated degradation (ERAD) of 3-hydroxy-3-methylglutaryl (HMG)-CoA reductase isozyme Hmg2. J. Biol. Chem. 2011, 286, 26298-26307. [CrossRef] [PubMed]

10. Di Scala, C.; Baier, C.J.; Evans, L.S.; Williamson, P.T.F.; Fantini, J.; Barrantes, F.J. Relevance of CARC and CRAC Cholesterol-Recognition Motifs in the Nicotinic Acetylcholine Receptor and Other Membrane-Bound Receptors. Curr. Top. Membr. 2017, 80, 3-23. [PubMed]

11. Russell, D.W. The Enzymes, Regulation, and Genetics of Bile Acid Synthesis. Annu. Rev. Biochem. 2003, 72, 137-174. [CrossRef] [PubMed]

12. Midzak, A.; Papadopoulos, V. Binding domain-driven intracellular trafficking of sterols for synthesis of steroid hormones, bile acids and oxysterols. Traffic 2014, 15, 895-914. [CrossRef] [PubMed]

13. Wang, T.J. Vitamin D and Cardiovascular Disease. Annu. Rev. Med. 2016, 67, 261-272. [CrossRef] [PubMed] 
14. Brown, M.; Goldstein, J. A receptor-mediated pathway for cholesterol homeostasis. Science 1986, $232,34-47$. [CrossRef] [PubMed]

15. Bloch, K. Sterol molecule: Structure, biosynthesis, and function. Steroids 1992, 57, 378-383. [CrossRef]

16. Dietschy, J.M.; Turley, S.D.; Spady, D.K. Role of liver in the maintenance of cholesterol and low density lipoprotein homeostasis in different animal species, including humans. J. Lipid Res. 1993, 34, 1637-1659. [PubMed]

17. Goedeke, L.; Fernández-Hernando, C. Regulation of cholesterol homeostasis. Cell. Mol. Life Sci. 2012, 69, 915-930. [CrossRef] [PubMed]

18. Horton, J.D.; Goldstein, J.L.; Brown, M.S. SREBPs: Activators of the complete program of cholesterol and fatty acid synthesis in the liver. J. Clin. Investig. 2002, 109, 1125-1131. [CrossRef] [PubMed]

19. Fears, R. The contribution of the cholesterol biosynthetic pathway to intermediary metabolism and cell function. Biochem. J. 1981, 199, 1-7. [CrossRef] [PubMed]

20. Goldstein, J.L.; Brown, M.S. The LDL Receptor. Arterioscler. Thromb. Vasc. Biol. 2009, 29, 431-438. [CrossRef] [PubMed]

21. Hussain, M.M. Intestinal lipid absorption and lipoprotein formation. Curr. Opin. Lipidol. 2014, 25, $200-206$. [CrossRef] [PubMed]

22. Betters, J.L.; Yu, L. NPC1L1 and cholesterol transport. FEBS Lett. 2010, 584, 2740-2747. [CrossRef] [PubMed]

23. Li, P.S.; Fu, Z.-Y.; Zhang, Y.-Y.; Zhang, J.-H.; Xu, C.-Q.; Ma, Y.-T.; Li, B.L.; Song, B.-L. The clathrin adaptor Numb regulates intestinal cholesterol absorption through dynamic interaction with NPC1L1. Nat. Med. 2014, 20, 80-86. [CrossRef] [PubMed]

24. Dash, S.; Xiao, C.; Morgantini, C.; Lewis, G.F. New Insights into the Regulation of Chylomicron Production. Annu. Rev. Nutr. 2015, 35, 265-294. [CrossRef] [PubMed]

25. Yoo, E. Sitosterolemia: A review and update of pathophysiology, clinical spectrum, diagnosis, and management. Ann. Pediatr. Endocrinol. Metab. 2016, 21, 7-14. [CrossRef] [PubMed]

26. Marcel, Y.L.; Innerarity, T.L.; Spilman, C.; Mahley, R.W.; Protter, A.A.; Milne, R.W. Mapping of human apolipoprotein B antigenic determinants. Arterioscler. Thromb. Vasc. Biol. 1987, 7, 166-175. [CrossRef]

27. Julve, J.; Martín-Campos, J.M.; Escolà-Gil, J.C.; Blanco-Vaca, F. Chylomicrons: Advances in biology, pathology, laboratory testing, and therapeutics. Clin. Chim. Acta 2016, 455, 134-148. [CrossRef] [PubMed]

28. Dixon, J.B. Mechanisms of chylomicron uptake into lacteals. Ann. N. Y. Acad. Sci. 2010, 1207, 52-57. [CrossRef] [PubMed]

29. Randolph, G.J.; Miller, N.E. Lymphatic transport of high-density lipoproteins and chylomicrons. J. Clin. Investig. 2014, 124, 929-935. [CrossRef] [PubMed]

30. Olivecrona, G. Role of lipoprotein lipase in lipid metabolism. Curr. Opin. Lipidol. 2016, 27, $233-241$. [CrossRef] [PubMed]

31. Wolska, A.; Dunbar, R.L.; Freeman, L.A.; Ueda, M.; Amar, M.J.; Sviridov, D.O.; Remaley, A.T. Apolipoprotein C-II: New findings related to genetics, biochemistry, and role in triglyceride metabolism. Atherosclerosis 2017, 267, 49-60. [CrossRef] [PubMed]

32. Dallinga-Thie, G.M.; Franssen, R.; Mooij, H.L.; Visser, M.E.; Hassing, H.C.; Peelman, F.; Kastelein, J.J.P.; Péterfy, M.; Nieuwdorp, M. The metabolism of triglyceride-rich lipoproteins revisited: New players, new insight. Atherosclerosis 2010, 211, 1-8. [CrossRef] [PubMed]

33. Heeren, J. Apolipoprotein E Recycling: Implications for Dyslipidemia and Atherosclerosis. Arterioscler. Thromb. Vasc. Biol. 2005, 26, 442-448. [CrossRef] [PubMed]

34. Frazier-Wood, A.C.; Kabagambe, E.K.; Wojczynski, M.K.; Borecki, I.B.; Tiwari, H.K.; Smith, C.E.; Ordovas, J.M.; Arnett, D.K. The association between LRP-1 variants and chylomicron uptake after a high fat meal. Nutr. Metab. Cardiovasc. Dis. 2013, 23, 1154-1158. [CrossRef] [PubMed]

35. Thompson, G.R.; Naoumova, R.P.; Watts, G.F. Role of cholesterol in regulating apolipoprotein B secretion by the liver. J. Lipid Res. 1996, 37, 439-447. [PubMed]

36. Ganesan, L.P.; Mates, J.M.; Cheplowitz, A.M.; Avila, C.L.; Zimmerer, J.M.; Yao, Z.; Maiseyeu, A.; Rajaram, M.V.S.; Robinson, J.M.; Anderson, C.L. Scavenger receptor B1, the HDL receptor, is expressed abundantly in liver sinusoidal endothelial cells. Sci. Rep. 2016, 6, 20646. [CrossRef] [PubMed]

37. Oude Elferink, R.P.; Groen, A. Mechanisms of biliary lipid secretion and their role in lipid homeostasis. Semin. Liver Dis. 2000, 20, 293-305. [CrossRef] [PubMed] 
38. Sirtori, C.R.; Pavanello, C.; Bertolini, S. Microsomal transfer protein (MTP) inhibition-A novel approach to the treatment of homozygous hypercholesterolemia. Ann. Med. 2014, 46, 464-474. [CrossRef] [PubMed]

39. Olofsson, S.O.; Borén, J. Apolipoprotein B secretory regulation by degradation. Arterioscler. Thromb. Vasc. Biol. 2012, 32, 1334-1338. [CrossRef] [PubMed]

40. Wang, Y.; Liu, L.; Zhang, H.; Fan, J.; Zhang, F.; Yu, M.; Shi, L.; Yang, L.; Lam, S.M.; Wang, H.; et al. Mea6 controls VLDL transport through the coordinated regulation of COPII assembly. Cell Res. 2016, 26, 787-804. [CrossRef] [PubMed]

41. Hossain, T.; Riad, A.; Siddiqi, S.; Parthasarathy, S.; Siddiqi, S.A. Mature VLDL triggers the biogenesis of a distinct vesicle from the trans-Golgi network for its export to the plasma membrane. Biochem. J. 2014, 459, 47-58. [CrossRef] [PubMed]

42. Doonan, L.M.; Fisher, E.A.; Brodsky, J.L. Can modulators of apolipoproteinB biogenesis serve as an alternate target for cholesterol-lowering drugs? BBA Mol. Cell Biol. Lipids 2018, 1863, 762-771. [CrossRef] [PubMed]

43. Tiwari, S.; Siddiqi, S.A. Intracellular trafficking and secretion of VLDL. Arterioscler. Thromb. Vasc. Biol. 2012, 32, 1079-1086. [CrossRef] [PubMed]

44. Nassir, F.; Adewole, O.L.; Brunt, E.M.; Abumrad, N.A. CD36 deletion reduces VLDL secretion, modulates liver prostaglandins, and exacerbates hepatic steatosis in ob/ob mice. J. Lipid Res. 2013, 54, 2988-2997. [CrossRef] [PubMed]

45. Etxebarria, A.; Benito-Vicente, A.; Stef, M.; Ostolaza, H.; Palacios, L.; Martin, C. Activity-associated effect of LDL receptor missense variants located in the cysteine-rich repeats. Atherosclerosis 2015, 238, 304-312. [CrossRef] [PubMed]

46. Soufi, M.; Rust, S.; Walter, M.; Schaefer, J.R. A combined LDL receptor/LDL receptor adaptor protein 1 mutation as the cause for severe familial hypercholesterolemia. Gene 2013, 521, 200-203. [CrossRef] [PubMed]

47. Reiner, Ž.; Reiner, Ž.; Guardamagna, O.; Nair, D.; Soran, H.; Hovingh, K.; Bertolini, S.; Ćorić, M.; Calandra, S.; Hamilton, J.; et al. Lysosomal acid lipase deficiency-An under-recognized cause of dyslipidaemia and liver dysfunction. Atherosclerosis 2014, 235, 21-30. [CrossRef] [PubMed]

48. Fernández-Higuero, J.A.; Benito-Vicente, A.; Etxebarria, A.; Milicua, J.C.G.; Ostolaza, H.; Arrondo, J.L.R.; Martín, C. Structural changes induced by acidic pH in human apolipoprotein B-100. Sci. Rep. 2016, 6, 36324. [CrossRef] [PubMed]

49. Etxebarria, A.; Benito-Vicente, A.; Palacios, L.; Stef, M.; Cenarro, A.; Civeira, F.; Ostolaza, H.; Martin, C. Functional characterization and classification of frequent low-density lipoprotein receptor variants. Hum. Mutat. 2015, 36, 129-141. [CrossRef] [PubMed]

50. Yu, X.-H.; Jiang, N.; Yao, P.-B.; Zheng, X.-L.; Cayabyab, F.S.; Tang, C.-K. NPC1, intracellular cholesterol trafficking and atherosclerosis. Clin. Chim. Acta 2014, 429, 69-75. [CrossRef] [PubMed]

51. Zhang, L.; Reue, K.; Fong, L.G.; Young, S.G.; Tontonoz, P. Feedback Regulation of Cholesterol Uptake by the LXR-IDOL-LDLR Axis. Arterioscler. Thromb. Vasc. Biol. 2012, 32, 2541-2546. [CrossRef] [PubMed]

52. Lopez, D. PCSK9: An enigmatic protease. BBA Mol. Cell Biol. Lipids 2008, 1781, 184-191. [CrossRef] [PubMed]

53. Horton, J.D.; Shah, N.A.; Warrington, J.A.; Anderson, N.N.; Park, S.W.; Brown, M.S.; Goldstein, J.L. Combined analysis of oligonucleotide microarray data from transgenic and knockout mice identifies direct SREBP target genes. Proc. Natl. Acad. Sci. USA 2003, 100, 12027-12032. [CrossRef] [PubMed]

54. Abifadel, M.; Varret, M.; Rabès, J.-P.; Allard, D.; Ouguerram, K.; Devillers, M.; Cruaud, C.; Benjannet, S.; Wickham, L.; Erlich, D.; et al. Mutations in PCSK9 cause autosomal dominant hypercholesterolemia. Nat. Genet. 2003, 34, 154-156. [CrossRef] [PubMed]

55. Zelcer, N.; Hong, C.; Boyadjian, R.; Tontonoz, P. LXR Regulates Cholesterol Uptake Through Idol-Dependent Ubiquitination of the LDL Receptor. Science 2009, 325, 100-104. [CrossRef] [PubMed]

56. Wierød, L.; Cameron, J.; Strøm, T.B.; Leren, T.P. Studies of the autoinhibitory segment comprising residues 31-60 of the prodomain of PCSK9: Possible implications for the mechanism underlying gain-of-function mutations. Mol. Genet. Metab. 2016, 9, 86-93. [CrossRef] [PubMed]

57. Luna Saavedra, Y.G.; Zhang, J.; Seidah, N.G. PCSK9 Prosegment Chimera as Novel Inhibitors of LDLR Degradation. PLoS ONE 2013, 8, e72113. [CrossRef] [PubMed]

58. Schroeder, C.I.; Swedberg, J.E.; Withka, J.M.; Rosengren, K.J.; Akcan, M.; Clayton, D.J.; Daly, D.L.; Cheneval, O.; Borzilleri, K.A.; Griffor, M.; et al. Design and Synthesis of Truncated EGF-A Peptides that Restore LDL-R Recycling in the Presence of PCSK9 In Vitro. Chem. Biol. 2014, 21, 284-294. [CrossRef] [PubMed] 
59. Gu, H.; Adijiang, A.; Mah, M.; Zhang, D. Characterization of the role of EGF-A of low density lipoprotein receptor in PCSK9 binding. J. Lipid Res. 2013, 54, 3345-3357. [CrossRef] [PubMed]

60. Wang, B.; Tontonoz, P. Liver X receptors in lipid signalling and membrane homeostasis. Nat. Rev. Endocrinol. 2018, 14, 452-463. [CrossRef] [PubMed]

61. Tontonoz, P.; Mangelsdorf, D.J. Liver X Receptor Signaling Pathways in Cardiovascular Disease. Mol. Endocrinol. 2003, 17, 985-993. [CrossRef] [PubMed]

62. Wang, S.; Mao, Y.; Narimatsu, Y.; Ye, Z.; Tian, W.; Goth, C.K.; Lira-Navarrete, E.; Pedersen, N.B.; Benito-Vicente, A.; Martin, C.; et al. Site-specific O-glycosylation of members of the low-density lipoprotein receptor superfamily enhances ligand interactions. J. Biol. Chem. 2018, 293, 7408-7422. [CrossRef] [PubMed]

63. Goedeke, L.; Wagschal, A.; Fernández-Hernando, C.; Näär, A.M. miRNA regulation of LDL-cholesterol metabolism. BBA Mol. Cell Biol. Lipids 2016, 1861, 2047-2052. [CrossRef] [PubMed]

64. Wagschal, A.; Najafi-Shoushtari, S.H.; Wang, L.; Goedeke, L.; Sinha, S.; deLemos, A.S.; Black, J.C.; Ramírez, C.M.; Li, Y.; Tewhey, R.; et al. Genome-wide identification of microRNAs regulating cholesterol and triglyceride homeostasis. Nat. Med. 2015, 21, 1290-1297. [CrossRef] [PubMed]

65. Ha, M.; Kim, V.N. Regulation of microRNA biogenesis. Nat. Rev. Mol. Cell Biol. 2014, 15, 509-524. [CrossRef] [PubMed]

66. Romero-Cordoba, S.L.; Salido-Guadarrama, I.; Rodriguez-Dorantes, M.; Hidalgo-Miranda, A. miRNA biogenesis: Biological impact in the development of cancer. Cancer Biol. Ther. 2014, 15, 1444-1455. [CrossRef] [PubMed]

67. Goedeke, L.; Rotllan, N.; Ramírez, C.M.; Aranda, J.F.; Canfrán-Duque, A.; Araldi, E.; Fernández-Hernando, A.; Langhi, C.; Cabo, R.D.; Baldán, Á.; et al. miR-27b inhibits LDLR and ABCA1 expression but does not influence plasma and hepatic lipid levels in mice. Atherosclerosis 2015, 243, 499-509. [CrossRef] [PubMed]

68. Alvarez, M.L.; Khosroheidari, M.; Eddy, E.; Done, S.C. MicroRNA-27a decreases the level and efficiency of the LDL receptor and contributes to the dysregulation of cholesterol homeostasis. Atherosclerosis 2015, 242, 595-604. [CrossRef] [PubMed]

69. Goedeke, L.; Rotllan, N.; Canfrán-Duque, A.; Aranda, J.F.; Ramírez, C.M.; Araldi, E.; Lin, C.-S.; Anderson, N.N.; Wagschal, A.; Cabo, R.d.; et al. MicroRNA-148a regulates LDL receptor and ABCA1 expression to control circulating lipoprotein levels. Nat. Med. 2015, 21, 1280-1288. [CrossRef] [PubMed]

70. Favari, E.; Chroni, A.; Tietge, U.J.; Zanotti, I.; Escolà-Gil, J.C.; Bernini, F. Handbook of Experimental Pharmacology; Springer: Cham, Switzerland, 2015; Volume 224, pp. 181-206.

71. Wang, S.; Smith, J.D. ABCA1 and nascent HDL biogenesis. BioFactors 2014, 40, 547-554. [CrossRef] [PubMed]

72. Zannis, V.I.; Chroni, A.; Krieger, M. Role of apoA-I, ABCA1, LCAT, and SR-BI in the biogenesis of HDL. J. Mol. Med. 2006, 84, 276-294. [CrossRef] [PubMed]

73. Terasaka, N.; Westerterp, M.; Koetsveld, J.; Fernández-Hernando, C.; Yvan-Charvet, L.; Wang, N.; Sessa, W.C.; Tall, A.R. ATP-binding cassette transporter G1 and high-density lipoprotein promote endothelial NO synthesis through a decrease in the interaction of caveolin-1 and endothelial NO synthase. Arterioscler. Thromb. Vasc. Biol. 2010, 30, 2219-2225. [CrossRef] [PubMed]

74. Gillard, B.K.; Rosales, C.; Xu, B., Jr.; Gotto, A.M.; Pownall, H.J. Rethinking reverse cholesterol transport and dysfunctional high-density lipoproteins. J. Clin. Lipidol. 2018, 12, 849-856. [CrossRef] [PubMed]

75. Wang, X.; Li, W.; Hao, L.; Xie, H.; Hao, C.; Liu, C.; Li, W.; Xiong, X.; Zhao, D. The therapeutic potential of CETP inhibitors: A patent review. Expert Opin. Ther. Pat. 2018, 28, 331-340. [CrossRef] [PubMed]

76. Dikkers, A.; Tietge, U.J.F. Biliary cholesterol secretion: More than a simple ABC. World J. Gastroenterol. 2010, 16, 5936-5945. [PubMed]

77. Halilbasic, E.; Claudel, T.; Trauner, M. Bile acid transporters and regulatory nuclear receptors in the liver and beyond. J. Hepatol. 2013, 58, 155-168. [CrossRef] [PubMed]

78. Norlin, M.; Wikvall, K. Enzymes in the Conversion of Cholesterol into Bile Acids. Curr. Mol. Med. 2007, 7, 199-218. [CrossRef] [PubMed]

79. Yu, X.H.; Qian, K.; Jiang, N.; Zheng, X.L.; Cayabyab, F.S.; Tang, C.K. ABCG5/ABCG8 in cholesterol excretion and atherosclerosis. Clin. Chim. Acta 2014, 428, 82-88. [CrossRef] [PubMed]

80. Bonamassa, B.; Moschetta, A. Atherosclerosis: Lessons from LXR and the intestine. Trends Endocrinol. Metab. 2013, 24, 120-128. [CrossRef] [PubMed]

81. Gordo-Gilart, R.; Andueza, S.; Hierro, L.; Jara, P.; Alvarez, L. Functional Rescue of Trafficking-Impaired ABCB4 Mutants by Chemical Chaperones. PLoS ONE 2016, 11, e0150098. [CrossRef] [PubMed] 
82. Cohen, D.E. Balancing cholesterol synthesis and absorption in the gastrointestinal tract. J. Clin. Lipidol. 2008, 2, 1-5. [CrossRef] [PubMed]

83. Ference, B.A.; Ginsberg, H.N.; Graham, I.; Ray, K.K.; Packard, C.J.; Bruckert, E.; Hegele, R.A.; Krauss, R.M.; Raal, F.J.; Schunkert, H.; et al. Low-density lipoproteins cause atherosclerotic cardiovascular disease. 1. Evidence from genetic, epidemiologic, and clinical studies. A consensus statement from the European Atherosclerosis Society Consensus Panel. Eur. Heart J. 2017, 38, 2459-2472. [CrossRef] [PubMed]

84. Vallejo-Vaz, A.J.; Akram, A.; Kondapally Seshasai, S.R.; Cole, D.; Watts, G.F.; Hovingh, G.K.; Kastelein, J.J.; Mata, P.; Raal, F.J.; Santos, R.D.; et al. Pooling and expanding registries of familial hypercholesterolaemia to assess gaps in care and improve disease management and outcomes: Rationale and design of the global EAS Familial Hypercholesterolaemia Studies Collaboration. Atheroscler. Suppl. 2016, 22, 1-32. [CrossRef] [PubMed]

85. Nordestgaard, B.G.; Chapman, M.J.; Humphries, S.E.; Ginsberg, H.N.; Masana, L.; Descamps, O.S.; Wiklund, O.; Hegele, R.A.; Raal, F.J.; Defesche, J.C.; et al. Familial hypercholesterolaemia is underdiagnosed and undertreated in the general population: Guidance for clinicians to prevent coronary heart disease. Eur. Heart J. 2013, 34, 3478-3490. [CrossRef] [PubMed]

86. Cenarro, A.; Etxebarria, A.; de Castro-Orós, I.; Stef, M.; Bea, A.M.; Palacios, L.; Mateo-Gallego, R.; Benito-Vicente, A.; Ostolaza, H.; Tejedor, T.; et al. The p.Leu167del mutation in APOE gene causes autosomal dominant hypercholesterolemia by down-regulation of LDL receptor expression in hepatocytes. J. Clin. Endocrinol. Metab. 2016, 101, 2113-2121. [CrossRef] [PubMed]

87. Fouchier, S.W.; Dallinga-Thie, G.M.; Meijers, J.C.; Zelcer, N.; Kastelein, J.J.; Defesche, J.C.; Hovingh, G.K. Mutations in STAP1 are associated with autosomal dominant hypercholesterolemia. Circ. Res. 2014, 115, 552-555. [CrossRef] [PubMed]

88. Rios, J.; Stein, E.; Shendure, J.; Hobbs, H.H.; Cohen, J.C. Identification by whole-genome resequencing of gene defect responsible for severe hypercholesterolemia. Hum. Mol. Genet. 2010, 19, 4313-4318. [CrossRef] [PubMed]

89. Landrum, M.J.; Lee, J.M.; Benson, M.; Brown, G.; Chao, C.; Chitipiralla, S.; Gu, B.; Hart, J.; Hoffman, D.; Hoover, J.; et al. ClinVar: Public archive of interpretations of clinically relevant variants. Nucleic Acids Res. 2016, 44, D862-D868. [CrossRef] [PubMed]

90. Defesche, J.C.; Gidding, S.S.; Harada-Shiba, M.; Hegele, R.A.; Santos, R.D.; Wierzbicki, A.S. Familial hypercholesterolaemia. Nat. Rev. Dis. Prim. 2017, 3, 17093. [CrossRef] [PubMed]

91. Iacocca, M.A.; Hegele, R.A. Role of DNA copy number variation in dyslipidemias. Curr. Opin. Lipidol. 2018, 29, 125-132. [CrossRef] [PubMed]

92. Etxebarria, A.; Palacios, L.; Stef, M.; Tejedor, D.; Uribe, K.B.; Oleaga, A.; Irigoyen, L.; Torres, B.; Ostolaza, H.; Martin, C. Functional characterization of splicing and ligand-binding domain variants in the LDL receptor. Hum. Mutat. 2012, 33, 232-243. [CrossRef] [PubMed]

93. Ho, C.K.M.; Musa, F.R.; Bell, C.; Walker, S.W. LDLR gene synonymous mutation c.1813C > T results in mRNA splicing variation in a kindred with familial hypercholesterolaemia. Ann. Clin. Biochem. 2015, 52, 680-684. [CrossRef] [PubMed]

94. Holla, Ø.L.; Kulseth, M.A.; Berge, K.E.; Leren, T.P.; Ranheim, T. Nonsense-mediated decay of human LDL receptor mRNA. Scand. J. Clin. Lab. Investig. 2009, 69, 409-417. [CrossRef] [PubMed]

95. Alves, A.C.; Benito-Vicente, A.; Medeiros, A.M.; Reeves, K.; Martin, C.; Bourbon, M. Further evidence of novel APOB mutations as a cause of Familial Hypercholesterolaemia. Atherosclerosis 2018. [CrossRef] [PubMed]

96. Alves, A.C.; Etxebarria, A.; Soutar, A.K.; Martin, C.; Bourbon, M. Novel functional APOB mutations outside LDL-binding region causing familial hypercholesterolaemia. Hum. Mol. Genet. 2014, 23, 1817-1828. [CrossRef] [PubMed]

97. Dron, J.S.; Hegele, R.A. Complexity of mechanisms among human proprotein convertase subtilisin-kexin type 9 variants. Curr. Opin. Lipidol. 2017, 28, 161-169. [CrossRef] [PubMed]

98. Mousavi, S.A.; Berge, K.E.; Leren, T.P. The unique role of proprotein convertase subtilisin/kexin 9 in cholesterol homeostasis. J. Intern. Med. 2009, 266, 507-519. [CrossRef] [PubMed]

99. Cohen, J.C.; Boerwinkle, E.; Mosley, T.H.; Hobbs, H.H. Sequence variations in PCSK9, low LDL, and protection against coronary heart disease. N. Eng. J. Med. 2006, 354, 1264-1272. [CrossRef] [PubMed] 
100. Berberich, A.J.; Hegele, R.A. The complex molecular genetics of familial hypercholesterolaemia. Nat. Rev. Cardiol. 2018. [CrossRef] [PubMed]

101. Soutar, A.K.; Naoumova, R.P. Mechanisms of disease: Genetic causes of familial hypercholesterolemia. Nat. Clin. Pract. Cardiovasc. Med. 2007, 4, 214-225. [CrossRef] [PubMed]

102. Quagliarini, F.; Quagliarini, F.; Vallvé, J.C.; Campagna, F.; Alvaro, A.; Fuentes-Jimenez, F.J.; Sirinian, M.I.; Meloni, F.; Masana, L.; Arca, M. Autosomal recessive hypercholesterolemia in Spanish kindred due to a large deletion in the ARH gene. Mol. Genet. Metab. 2007, 92, 243-248. [CrossRef] [PubMed]

103. Tada, H.; Nomura, A.; Yamagishi, M.; Kawashiri, M.A. First case of sitosterolemia caused by double heterozygous mutations in ABCG5 and ABCG8 genes. J. Clin. Lipidol. 2018. [CrossRef] [PubMed]

104. Wang, W.; Jiang, L.; Chen, P.P.; Wu, Y.; Su, P.Y.; Wang, L.Y. A case of sitosterolemia misdiagnosed as familial hypercholesterolemia: A 4-year follow-up. J. Clin. Lipidol. 2018, 12, 236-239. [CrossRef] [PubMed]

105. Muso, E. Beneficial effect of LDL-apheresis in refractory nephrotic syndrome. Clin. Exp. Nephrol. 2014, 18, 286-290. [CrossRef] [PubMed]

106. Agrawal, S.; Zaritsky, J.J.; Fornoni, A.; Smoyer, W.E. Dyslipidaemia in nephrotic syndrome: Mechanisms and treatment. Nat. Rev. Nephrol. 2017, 14, 57-70. [CrossRef] [PubMed]

107. Chrostek, L.; Supronowicz, L.; Panasiuk, A.; Cylwik, B.; Gruszewska, E.; Flisiak, R. The effect of the severity of liver cirrhosis on the level of lipids and lipoproteins. Clin. Exp. Med. 2014, 14, 417-421. [CrossRef] [PubMed]

108. Rizos, C.V.; Elisaf, M.S.; Liberopoulos, E.N. Effects of thyroid dysfunction on lipid profile. Open Cardiovasc. Med. J. 2011, 5, 76-84. [CrossRef] [PubMed]

109. Nemes, K.; Åberg, F.; Gylling, H.; Isoniemi, H. Cholesterol metabolism in cholestatic liver disease and liver transplantation: From molecular mechanisms to clinical implications. World J. Hepatol. 2016, 8, 924. [CrossRef] [PubMed]

110. Mozaffarian, D.; Benjamin, E.J.; Go, A.S.; Arnett, D.K.; Blaha, M.J.; Cushman, M.; de Ferranti, S.; Després, J.P.; Fullerton, H.J.; Howard, V.J.; et al. Heart disease and stroke statistics-2015 update: A report from the American Heart Association. Circulation 2015, 131, 434-441. [CrossRef]

111. Schwenke, D.C.; Carew, T.E. Initiation of atherosclerotic lesions in cholesterol-fed rabbits. II. Selective retention of LDL vs. selective increases in LDL permeability in susceptible sites of arteries. Arteriosclerosis 1989, 9, 908-918. [CrossRef] [PubMed]

112. Davies, P.F. Flow-mediated endothelial mechanotransduction. Physiol. Rev. 1995, 75, 519-560. [CrossRef] [PubMed]

113. Galkina, E.; Ley, K. Vascular adhesion molecules in atherosclerosis. Arterioscler. Thromb. Vasc. Biol. 2007, 27, 2292-2301. [CrossRef] [PubMed]

114. Moore, K.J.; Freeman, M.W. Scavenger receptors in atherosclerosis: Beyond lipid uptake. Arterioscler. Thromb. Vasc. Biol. 2006, 26, 1702-1711. [CrossRef] [PubMed]

115. Libby, P. Changing concepts of atherogenesis. J. Intern. Med. 2000, 247, 349-358. [CrossRef] [PubMed]

116. Heusch, G.; Libby, P.; Gersh, B.; Yellon, D.; Böhm, M.; Lopaschuk, G.; Opie, L. Cardiovascular remodelling in coronary artery disease and heart failure. Lancet 2014, 383, 1933-1943. [CrossRef]

117. Bench, T.J.; Jeremias, A.; Brown, D.L. Matrix metalloproteinase inhibition with tetracyclines for the treatment of coronary artery disease. Pharmacol. Res. 2011, 64, 561-566. [CrossRef] [PubMed]

118. Scientific Steering Committe on behalf of the Simon Broome Register Group. Risk of fatal coronary heart disease in familial hypercholesterolaemia. BMJ 1991, 303, 893-896. [CrossRef]

119. Williams, R.R.; Hunt, S.C.; Schumacher, M.C.; Hegele, R.A.; Leppert, M.F.; Ludwig, E.H.; Hopkins, P.N. Diagnosing heterozygous familial hypercholesterolemia using new practical criteria validated by molecular genetics. Am. J. Cardiol. 1993, 72, 171-176. [CrossRef]

120. Ito, M.K.; Watts, G.F. Challenges in the Diagnosis and Treatment of Homozygous Familial Hypercholesterolemia. Drugs 2015, 75, 1715-1724. [CrossRef] [PubMed]

121. Gagné, C.; Gaudet, D.; Bruckert, E. Efficacy and safety of ezetimibe coadministered with atorvastatin or simvastatin in patients with homozygous familial hypercholesterolemia. Circulation 2002, 105, 2469-2475. [CrossRef] [PubMed] 
122. Raal, F.J.; Santos, R.D.; Blom, D.J.; Marais, A.D.; Charng, M.J.; Cromwell, W.C.; Lachmann, R.H.; Gaudet, D.; Tan, J.L.; Chasan-Taber, S.; et al. Mipomersen, an apolipoprotein B synthesis inhibitor, for lowering of LDL cholesterol concentrations in patients with homozygous familial hypercholesterolaemia: A randomised, double-blind, placebo-controlled trial. Lancet 2010, 375, 998-1006. [CrossRef]

123. ENDO, A. A historical perspective on the discovery of statins. Proc. Jpn. Acad. Ser. B 2010, 86, 484-493. [CrossRef]

124. Marais, A.D.; Raal, F.J.; Stein, E.A.; Rader, D.J.; Blasetto, J.; Palmer, M.; Wilpshaar, W. A dose-titration and comparative study of rosuvastatin and atorvastatin in patients with homozygous familial hypercholesterolaemia. Atherosclerosis 2008, 197, 400-406. [CrossRef] [PubMed]

125. Mason, R.P.; Walter, M.F.; Day, C.A.; Jacob, R.F. Intermolecular differences of 3-hydroxy-3-methylglutaryl coenzyme a reductase inhibitors contribute to distinct pharmacologic and pleiotropic actions. Am. J. Cardiol. 2005, 96, 11F-23F. [CrossRef] [PubMed]

126. Schachter, M. Chemical, pharmacokinetic and pharmacodynamic properties of statins: An update. Fundam. Clin. Pharmacol. 2005, 19, 117-125. [CrossRef] [PubMed]

127. Germershausen, J.I.; Hunt, V.M.; Bostedor, R.G.; Bailey, P.J.; Karkas, J.D.; Alberts, A.W. Tissue selectivity of the cholesterol-lowering agents lovastatin, simvastatin and pravastatin in rats in vivo. Biochem. Biophys. Res. Commun. 1989, 158, 667-675. [CrossRef]

128. McKenney, J.M. Pharmacologic characteristics of statins. Clin. Cardiol. 2003, 26, 32-38. [CrossRef] [PubMed]

129. Stroes, E.S.; Thompson, P.D.; Corsini, A.; Vladutiu, G.D.; Raal, F.J.; Ray, K.K.; Roden, M.; Stein, E.; Tokgözoğlu, L.; Nordestgaard, B.G.; et al. Statin-associated muscle symptoms: Impact on statin therapy-European Atherosclerosis Society Consensus Panel Statement on Assessment, Aetiology and Management. Eur. Heart J. 2015, 36, 1012-1022. [CrossRef] [PubMed]

130. Sattar, N.; Preiss, D.; Murray, H.M. Statins and risk of incident diabetes: A collaborative meta-analysis of randomised statin trials. Rev. Port. Cardiol. 2010, 29, 1077-1078. [CrossRef]

131. Mach, F.; Ray, K.K.; Wiklund, O.; Corsini, A.; Catapano, A.L.; Bruckert, E.; De Backer, G.; Hegele, R.A.; Hovingh, G.K.; Jacobson, T.A.; et al. Adverse effects of statin therapy: Perception vs. the evidence-Focus on glucose homeostasis, cognitive, renal and hepatic function, haemorrhagic stroke and cataract. Eur. Heart J. 2018, 39, 2526-2539. [CrossRef] [PubMed]

132. Gille, A.; Bodor, E.T.; Ahmed, K.; Offermanns, S. Nicotinic Acid: Pharmacological Effects and Mechanisms of Action. Annu. Rev. Pharmacol. Toxicol. 2008, 48, 79-106. [CrossRef] [PubMed]

133. Julius, U. History of lipidology and lipoprotein apheresis. Atheroscler 2017, 30, 1-8. [CrossRef] [PubMed]

134. Chang, Y.; Robidoux, J. Dyslipidemia management update. Curr. Opin. Pharmacol. 2017, 33, 47-55. [CrossRef] [PubMed]

135. Scaldaferri, F.; Pizzoferrato, M.; Ponziani, F.R.; Gasbarrini, G.; Gasbarrini, A. Use and indications of cholestyramine and bile acid sequestrants. Int. Emerg. Med. 2013, 8, 205-210. [CrossRef] [PubMed]

136. Davidson, M.H. A systematic review of bile acid sequestrant therapy in children with familial hypercholesterolemia. J. Clin. Lipidol. 2011, 5, 76-81. [CrossRef] [PubMed]

137. Altmann, S.W. Niemann-Pick C1 Like 1 Protein Is Critical for Intestinal Cholesterol Absorption. Science 2004, 303, 1201-1204. [CrossRef] [PubMed]

138. Temel, R.E.; Tang, W.; Ma, Y.; Rudel, L.L.; Willingham, M.C.; Ioannou, Y.A.; Davies, J.P.; Nilsson, L.M.; Yu, L. Hepatic Niemann-Pick C1-like 1 regulates biliary cholesterol concentration and is a target of ezetimibe. J. Clin. Investig. 2007, 117, 1968-1978. [CrossRef] [PubMed]

139. Rosenson, R.S.; Hegele, R.A.; Fazio, S.; Cannon, C.P. The Evolving Future of PCSK9 Inhibitors. J. Am. Coll. Cardiol. 2018, 72, 314-329. [CrossRef] [PubMed]

140. Robinson, J.G.; Huijgen, R.; Ray, K.; Persons, J.; Kastelein, J.J.; Pencina, M.J. Determining When to Add Nonstatin Therapy. J. Am. Coll. Cardiol. 2016, 68, 2412-2421. [CrossRef] [PubMed]

141. Zodda, D.; Giammona, R.; Schifilliti, S. Treatment Strategy for Dyslipidemia in Cardiovascular Disease Prevention: Focus on Old and New Drugs. Pharmacy 2018, 6, 10. [CrossRef] [PubMed]

142. Polychronopoulos, G.; Tziomalos, K. Novel treatment options for the management of heterozygous familial hypercholesterolemia. Expert Rev. Clin. Pharmacol. 2017, 10, 1375-1381. [CrossRef] [PubMed]

143. Thompson, G.R.; Catapano, A.; Saheb, S.; Atassi-Dumont, M.; Barbir, M.; Eriksson, M.; Paulweber, B.; Sijbrands, E.; Stalenhoef, A.F.; Parhofer, K.G. Severe hypercholesterolaemia: Therapeutic goals and eligibility criteria for LDL apheresis in Europe. Curr. Opin. Lipidol. 2010, 21, 492-498. [CrossRef] [PubMed] 
144. Julius, U. Current Role of Lipoprotein Apheresis in the Treatment of High-Risk Patients. J. Cardiovasc. Dev. Dis. 2018, 5, 27. [CrossRef] [PubMed]

145. Catapano, A.L.; Reiner, Z.; De Backer, G.; Graham, I.; Taskinen, M.R.; Wiklund, O.; Agewall, S.; Alegria, E.; Chapman, M.; Durrington, P.; et al. ESC/EAS Guidelines for the management of dyslipidaemias the Task Force for the management of dyslipidaemias of the European Society of Cardiology (ESC) and the European Atherosclerosis Society (EAS). Eur. Heart J. 2011, 217, 3-46.

146. Gylling, H.; Plat, J.; Turley, S.; Ginsberg, H.N.; Ellegård, L.; Jessup, W.; Jones, P.J.; Lütjohann, D.; Maerz, W.; Masana, L.; et al. Plant sterols and plant stanols in the management of dyslipidaemia and prevention of cardiovascular disease. Atherosclerosis 2014, 232, 346-360. [CrossRef] [PubMed]

147. Shishikura, Y.; Khokhar, S.; Murray, B.S. Effects of tea polyphenols on emulsification of olive oil in a small intestine model system. J. Agric. Food Chem. 2006, 54, 1906-1913. [CrossRef] [PubMed]

148. Cameron, J.; Ranheim, T.; Kulseth, M.A.; Leren, T.P.; Berge, K.E. Berberine decreases PCSK9 expression in HepG2 cells. Atherosclerosis 2008, 201, 266-273. [CrossRef] [PubMed]

149. Li, H.; Dong, B.; Park, S.W.; Lee, H.S.; Chen, W.; Liu, J. Hepatocyte Nuclear Factor $1 \alpha$ Plays a Critical Role in PCSK9 Gene Transcription and Regulation by the Natural Hypocholesterolemic Compound Berberine. J. Biol. Chem. 2009, 284, 28885-28895. [CrossRef] [PubMed]

150. Chen, C.; Yang, J.; Uang, Y.; Lin, C. Improved dissolution rate and oral bioavailability of lovastatin in red yeast rice products. Int. J. Pharm. 2013, 444, 18-24. [CrossRef] [PubMed]

151. Steering, S.; Register, B. Mortality in treated heterozygous familial hypercholesterolaemia: Implications for clinical management. Scientific Steering Committee on behalf of the Simon Broome Register Group. Atherosclerosis 1999, 142, 105-112.

152. Palacios, L.; Grandoso, L.; Cuevas, N.; Olano-Martín, E.; Martinez, A.; Tejedor, D.; Stef, M. Molecular characterization of familial hypercholesterolemia in Spain. Atherosclerosis 2012, 221, 137-142. [CrossRef] [PubMed]

153. Civeira, F.; Ros, E.; Jarauta, E.; Plana, N.; Zambon, D.; Puzo, J.; Martinez de Esteban, J.P.; Ferrando, J.; Zabala, S.; Almagro, F.; et al. Comparison of Genetic versus Clinical Diagnosis in Familial Hypercholesterolemia. Am. J. Cardiol. 2008, 102, 1187-1193. [CrossRef] [PubMed]

154. Starr, B.; Hadfield, S.G.; Hutten, B.A.; Lansberg, P.J.; Leren, T.P.; Damgaard, D.; Neil, H.A.; Humphries, S.E. Development of sensitive and specific age- and gender- specific low-density lipoprotein cholesterol cutoffs for diagnosis of first-degree relatives with familial hypercholesterolaemia in cascade testing. Clin. Chem. Lab. Med. 2008, 46, 791-803. [CrossRef] [PubMed]

155. Benito-Vicente, A.; Alves, A.C.; Etxebarria, A.; Medeiros, A.M.; Martin, C.; Bourbon, M. The importance of an integrated analysis of clinical, molecular, and functional data for the genetic diagnosis of familial hypercholesterolemia. Genet. Med. 2015, 17, 980-988. [CrossRef] [PubMed]

156. Huijgen, R.; Kindt, I.; Defesche, J.C.; Kastelein, J.J.P. Cardiovascular risk in relation to functionality of sequence variants in the gene coding for the low-density lipoprotein receptor: A study among 29,365 individuals tested for 64 specific low-density lipoprotein-receptor sequence variants. Eur. Heart J. 2012, 33, 2325-2330. [CrossRef] [PubMed]

157. Strøm, T.B.; Tveten, K.; Leren, T.P. PCSK9 acts as a chaperone for the LDL receptor in the endoplasmic reticulum. Biochem. J. 2014, 457, 99-105. [CrossRef] [PubMed]

158. Benito-Vicente, A.; Uribe, K.B.; Jebari, S.; Galicia-Garcia, U.; Ostolaza, H.; Martin, C. Validation of LDLr Activity as a Tool to Improve Genetic Diagnosis of Familial Hypercholesterolemia: A Retrospective on Functional Characterization of LDLr Variants. Int. J. Mol. Sci. 2018, 19, 1676. [CrossRef] [PubMed]

(C) 2018 by the authors. Licensee MDPI, Basel, Switzerland. This article is an open access article distributed under the terms and conditions of the Creative Commons Attribution (CC BY) license (http:/ / creativecommons.org/licenses/by/4.0/). 